\title{
Jewish Art in Its Late Antique Context
}

\author{
Ed. by Uzi Leibner and Catherine Hezser
}

[Jüdische Kunst in ihrem spätantiken Kontext.]

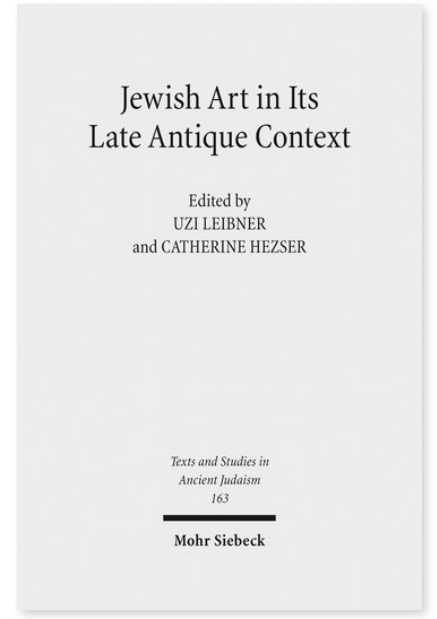

2016. IX, 381 Seiten. TSAJ 163

ISBN 978-3-16-154389-0

DOI 10.1628/978-3-16-154389-0

eBook PDF $184,00 €$

ISBN 978-3-16-154388-3

Leinen $184,00 €$
Veröffentlicht auf Englisch.

Die Beiträge dieses Bandes bieten erstmals einen interdisziplinären Ansatz zum besseren Verständnis der Entstehung und Entwicklung jüdischer Kunst in der spätantiken und frühbyzantinischen Zeit. Indem jüdische Kunst im Kontext der spätantiken paganen und christlichen Kunst, Kultur, und Gesellschaft verstanden wird, können Analogien und Wechselwirkungen aufgezeigt werden, die sowohl auf Gemeinsamkeiten als auch auf unterschiedliche Bedeutungszusammenhänge hinweisen Warum gibt es figürliche Darstellungen erst im Judentum der Spätantike? Wie verhält sich diese Kunst zum Anikonismus der Bibel und des rabbinischen Judentums? Muss man Erwin Goodenough recht geben, der behauptete, es gäbe einen krassen Gegensatz zwischen der Synagogenkunst und den Rabbinen? Durch die gemeinsame Betrachtung literarischer und archäologischer Quellen sowie jüdischer, christlicher, und paganer Kunst, erscheint die Kunst der Spätantike in neuem Licht.

Inhaltsübersicht

Catherine Hezser/Uzi Leibner: Jewish Art in its Late Antique Context: An Introductory Essay

\section{Part I: The Development of Jewish Art in the Roman-Byzantine Period}

Orit Peleg-Barkat: Interpreting the Uninterpreted: Art as a Means of Expressing Identity in Early Roman Judaea - Lee I. Levine: Why Did Jewish Art Flourish in Late Antiquity? - Peter Stewart: The Bet Alpha Synagogue Mosaic and Late-Antique Provincialism - Rina Talgam: From Wall Paintings to Floor Mosaics: Jewish and Christian Attitudes to Figurative Art

\section{Part II: Synagogue Mosaic Panels}

Zeev Weiss: Decorating the Sacred Realm: Biblical Depictions in Synagogues and Churches of Ancient Palestine - Uzi Leibner: Rabbinic Traditions and Synagogue Art - Roland Deines: God's Revelation Through Torah, Creation, and History: Interpreting the Zodiac Mosaics in Synagogues

Part III: Symbols and Iconography

Rachel Hachlili: Why Did the Menorah and Not the Showbread Table Evolve into the Most Important Symbol of Judaism? Catherine Hezser: »For the Lord God is a Sun and a Shield« (Ps. 84:12): Sun Symbolism in Hellenistic Jewish Literature and in Amoraic Midrashim - Karen B. Stern: Celebrating the Mundane: Figural Graffiti and Daily Life among Jews in the Levant

Part IV: Jewish and Christian Art

Markus Vinzent: Earliest 'Christian' Art is Jewish Art - Sean V. Leatherbury: Competitive Sacrifice: Christian Visual Engagement with Jewish Sacrificial History and the Temple in Late Antique Arabia - Robin M. Jensen: The Three Hebrew Youths and the Problem of the Emperor's Portrait in Early Christianity - Holger Zellentin: The Rabbis on (the Christianisation of) the Imperial Cult: Mishnah and Yerushalmi Avodah Zarah 3:1 (42b, 54-42c, 61)

Uzi Leibner 2004 PhD in archaeology from Bar Ilan University; currently a senior lecturer in Classical Archaeology at the Institute of Archaeology in the Hebrew University of Jerusalem.

Catherine Hezser 1986 Promotion in Ev. Theologie in Heidelberg mit Schwerpunkt Neues Testament; 1992 Promotion in Jewish Studies am Jewish Theological Seminary in New York; 1997 Habilitation an der FU Berlin; seit 2005 Professorin für Jewish Studies an der School of Oriental and African Studies (SOAS) der University of London. https://orcid.org/0000-0001-5246-6898

Jetzt bestellen:

https://mohrsiebeck.com/buch/jewish-art-in-its-late-antique-context-9783161543890?no_cache=1 order@mohrsiebeck.com

Telefon: +49 (0)7071-923-17

Telefax: $+49(0) 7071-51104$ 